\title{
Pengaruh Likuiditas, Ukuran Perusahaan dan Volatilitas Laba Terhadap Leverage Pada Perusahaan Terdaftar di Bursa Efek Indonesia
}

\author{
Habibatul Hidayati ${ }^{1, *}$, Gina Septiana ${ }^{2}$ \\ ${ }^{1}$ Program Studi Manajemen, Sekolah Tinggi Ilmu Ekonomi KBP, Kota Padang, Indonesia \\ ${ }^{2}$ Program Studi Akuntansi, Sekolah Tinggi Ilmu Ekonomi KBP, Kota Padang, Indonesia \\ Email: 1," habibatulhidayati@akbpstie.ac.id, ${ }^{2}$ ginaseptiana@akbpstie.ac.id \\ Email Penulis Korespondensi: habibatulhidayati@akbpstie.ac.id \\ Submitted: 17/11/2021; Accepted: 28/11/2021; Published: 30/11/2021
}

\begin{abstract}
Abstrak-Pada dunia bisnis saat Covid 19 melanda mengakibatkan persaingan kompetitif antar perusahaan melemah, jika ingin tetap memiliki keunggulan dalam daya saing, perusahaan senantiasa dituntut untuk dapat menjalankan operasi perusahaan secara efisien. Perusahaan menggunakan laba ditahan sebagai cadangan jika di kemudian hari perusahaan mengalami kerugian, pelunasan utang perusahaan, menambah modal kerja, dan sebagai dana ekspansi perusahaan yang mendatang. Tambahan penyertaan modal pemilik, beserta menerbitkan saham baru atau penjualan obligasi maupun kredit bank merupakan sumber dana eksternal atau dana yang berasal dari luar perusahaan itu sendiri (Cahyani, 2017).Tujuan penelitian ini untuk mengetahui pengaruh likuiditas, ukuran perusahaan dan volatilitas laba terhadap leverage. Sampel yang digunakan adalah semua perusahaan yang terdaftar di Bursa Efek Indonesia pada tahun 2015-2019 berjumlah 604 sampel. Jenis data yang digunakan adalah data sekunder. Hipotesis dalam penelitian diuji dengan menggunakan regresi data panel. Hasil penelitian menunjukkan bahwa likuiditas berpengaruh negatif terhadap leverage, sedangkan ukuran perusahaan berpengaruh positif terhadap leverage. Disisi lain, volatilitas laba tidak berpengaruh terhadapap hutang atau leverage perusahaan.
\end{abstract}

Kata Kunci: Likuiditas; Ukuran Perusahaan; Volatilitas Laba; Leverage

\begin{abstract}
In the business world when Covid 19 hit, the competitive competition between companies weakened. If you want to continue to have an advantage in competitiveness, companies are always required to be able to run company operations efficiently. The company uses retained earnings as a reserve if the company suffers a loss in the future, pays off company debt, increases working capital, and as funds for the company's future expansion. Additional owner's equity participation, along with issuing new shares or selling bonds or bank loans are sources of external funds or funds originating from outside the company itself (Cahyani, 2017). The purpose of this study was to determine the effect of liquidity, company size and earnings volatility on leverage. The sample used is all companies listed on the Indonesia Stock Exchange in 2015-2019 totaling 604 samples. The type of data used is secondary data. The hypotheses in the study were tested using panel data regression. The results showed that liquidity had a negative effect on leverage, while firm size had a positive effect on leverage. On the other hand, earnings volatility has no effect on debt or company leverage.
\end{abstract}

Keywords: Liquidity; Firm Size; Volatility Profit; Leverage

\section{PENDAHULUAN}

Pada dunia bisnis saat ini mengakibatkan persaingan kompetitif antar perusahaan, jika ingin tetap memiliki keunggulan dalam daya saing, perusahaan senantiasa dituntut untuk dapat menjalankan operasi perusahaan secara efisien. Perusahaan tidak hanya bertujuan untuk memaksimalkan keuntungan, tetapi juga berusaha untuk meningkatkan nilai perusahaan dan kemakmuran pemiliknya. Dalam perusahaan, seorang manajer harus teliti dalam memilih biaya dari berbagai sumber pendanaan, karena masing-masing dari pendanaan mempunyai risik masing-masing. Dana internal digunakan oleh perusahaan untuk suatu kegiatan investasi dan operasionalnya, yang termasuk dana internal perusahaan itu seperti laba ditahan, jika dana internal tidak mampu memenuhi kegiatan perusahaan maka di gabung dengan dana dari luar perusahaan (eksternal) seperti penjualan obligasi atau penerbitan saham baru (Alib, 2014).

Perusahaan dapat menggunakan laba ditahan sebagai cadangan jika di kemudian hari perusahaan mengalami kerugian, pelunasan utang perusahaan, menambah modal kerja, dan digunakan dalam membelanjai ekspansi perusahaan yang mendatang. Tambahan penyertaan modal pemilik, beserta menerbitkan saham baru atau penjualan obligasi maupun kredit bank merupakan sumber dana eksternal atau dana yang berasal dari luar perusahaan itu sendiri (Cahyani, 2017).

PT. Pemeringkat Efek Indonesia (Pefindo) menurunkan peringkat PT Semen Indonesia Tbk (SMGR) dari sebelumnya id AA+ menjadi AA. Penurunan peringkat ini juga termasuk untuk penawaran umum berkelanjutan (PUB) obligasi 1 tahun 2017 dan 2019. Alasannya leverage keuangan SMGR diperkirakan bakal tetap tinggi, yang berasal dari akuisisi PT Holcim Indonesia yang kini berubah menjadi PT Solusi Bangun Indonesia (SBI). Meski demikian, outlook SMGR direvisi menjadi stabil, dari sebelumnya negatif. Menurut pefindo, sinergi antara SBI dan SMGR ternyata lebih lambat dari ekpektasi, terutama kondisi industri semen yang masih lemah. Apalagi 70\% dari produk semen nasional dikonsumsi sektor properti yang juga tengah melambat. Pada semester 1 2019, leverage SMGR yang diukur dengan debt to EBITDA naik menjadi 5,4 kali. Sedangkan EBITDA to interest SMGR juga melemah menjadi 2.1 kali. Sehingga, rasio itu tidak sepadan untuk peringkat AA+. Peringkat AA yang diberikan maih menunjukkan posisi SMGR yang kuat diindustri semen. Hanya saja, prospek ini terkendala oleh leverage SMGR yang tinggi dan kompetisi di industri semen yang ketat. Selain itu SMGR juga rentan terkena paparan volatilitas di ektor properti dan konstruksi (Kontan, 2019).

Ada cara yang dapat dilakukan oleh perusahaan untuk mengurangi arus kas yang berlebihan yaitu dengan menyalurkan kembali kepada para pemegang saham melalui dividen yang lebih tinggi atau dengan membeli kembali 
saham (Fahmi, 2017). Hal ini juga dijelaskan oleh pecking order theory yang mana perusahaan lebih mengutamakan dana internal untuk membiayai kegiatan investasinya, jika mengalami kekurangan maka perusahaan akan memanfaatkan dana eksternal (Ririt, 2017).

Likuiditas merupakan suatu kemampuan perusahaan untuk membayar utang jangka pendek dengan sumber dana jangka pendek (lancar). Perusahaan yang memiliki likuiditas yang tinggi tidak akan memanfaatkan pembiayaan dari utang, karena itu menunjukan bahwa perusahaan mempunyai dana internal yang besar (Fahmi, 2017). Likuiditas menggambarkan kemampuan suatu perusahaan untuk membayar kewajiban finansial dengan segera (sesuai jangka jatuh tempo) (Yusra, Hadya, Fernandes, 2017).

Ukuran perusahaan merupakan besar kecilnya perusahaan yang ditunjukan dari total aktiva jumlah penjualan, ratarata total penjualan asset dan rata-rata total aktiva. Perusahaan yang mempunyai ukuran perusahaan yang besar cenderung banyak memanfaatkan hutang sehingga struktur modal membesar, ini disebabkan perusahaan membutuhkan dana yang besar untuk menunjang operasionalnya, sebaliknya perusahaan lebih sedikit memanfaatkan utang jika memiliki ukuran perusahaan yang kecil (Ririt, 2017).

Volatilitas mengacu pada seberapa stabil, atau tidak stabil pendapatan perusahaan. Untuk berinvestasi diperusahaan yang penghasilannya selalu berfluktuasi adalah keputusan berisiko bagi investor. Laba yang mudah naik akan membuat sangat sulit bagi manajemen untuk meminjam dana untuk investasi jangka panjang sehingga arus kas yang diperkirakan untuk memenuhi kewajiban utang mungkin tidak terwujud. Hal ini dapat berarti masalah serius, bahkan mengakibatkan penyitaan aset oleh pemberi pinjaman dan dalam kasus yang ekstrim, kebangkrutan (Yeo, 2016). Penelitian ini bertujuan untuk menguji dan menganalisis Pengaruh Likuiditas, Ukuran Perusahaan dan Volatilitas laba terhadap Leverage. Urgensi dari penelitian ini adalah mengembangkan model statistik.

\section{Agency Theory, Pecking Order Theory dan Signalling Theory}

Agency teori ini mucul karena disebabkan adanya pemisahan fungsi antara pemilik dengan pengelola, ini disebabkan perusahaan tidak mampu lagi memenuhi kebutuhan dananya dengan mengandalkan satu pemilik. Agency theory ini mengemukakan bahwa terjadi konflik antara pemilik (pemegang saham) dengan manajer perusahaan (agen), manajer perusahaan dapat melakukan tindakan yang dapat mengorbankan kepentingan pemegang saham dan lebih mengutamakan kesejahteraannya (Cahyani, 2017).

Adapun pengertian dari signalling theory yaitu kebijakan manajemen suatu perusahaan memberikan petunjuk bagi para investor mengenai manajemen perusahaan dalam memandang prospek kedepannya. Perusahaan yang mempunyai prospek akan memberikan keuntungan sehingga perusahaan akan mencoba menghindari penjualan saham, sehingga setiap modal baru yang dibutuhkan dapat dijaga dengan cara memanfaatkan hutang yang melebihi struktur modal yang normal. Jika perusahaan yang memiliki prospek yang kurang menguntungkan lebih cenderung untuk menjual sahamnya (Cahyani, 2017).

Pecking Order Theory mengatakan tingkat utang rendah jika perusahaan memiliki tingkat keuntungan yang besar. Ini disebabkan karena perusahaan yang memiliki keuntungan yang besar menunjukan peruahaan tersebut memiliki dana internal yang besar, sehingga tidak memerlukan tingkat utang yang besar. Dalam teori ini menerangkan manajer keuangan perusahaan tidak memperhitungkan tingkat hutang yang optimal. Kebutuhan dana di tentukan oleh kebutuhan investasi. Jika ada kesempatan melakukan investasi, maka perusahaan akan mencari dana untuk membiayai kebutuhan investasi tersebut, yang dimulai dari dana internal perusahaan,utang, dan menerbitkan saham (Cahyani, 2017).

\section{METODE PENELITIAN}

Dalam penelitian ini digunakan penelitian kuantitatif, yaitu metode yang filsafat positivism sebagai landasan yang dapat digunakan untuk meneliti filsafat sampel tertentu, menggunakan instrumen penelitian dalam pengumpulan data, dan analisis datanya bersifat statistik dan kuantitatif untuk menguji dan menggambarkan hipotesis yang sudah ditetapkan. Populasi yaitu suatu wilayah generalisasi yang terdiri dari objek yang mempunyai kuantitas dan karakteristik tertentu yang ditetapkan oleh peneliti untuk di pelajari dan kemudian ditarik kesimpulannya maka yang menjadi populasi penelitian ini adalah perusahaan yang terdaftar pada Bursa Efek Indonesia di akhir periode observasi, yaitu 2019 sebanyak 640 Perusahaan. Metode pemilahan sampel pada pengamatan ini dilakukan dengan metode purposive sampling yaitu metode penarikan sampel dengan penilaian yang berdasarkan pada kategori sesuai dengan objek maupun subjek yang untuk diamati. Teknik pengumpulan data yang digunakan adalah dokumentasi yang bisa di akses melalui www.idx.co.id, web.idx.id.

\subsection{Kerangka Dasar Penelitian}

\section{a. Pengaruh Likuiditas terhadap Leverage}

Likuiditas berguna untuk mengukur kemampuan perusahaan dalam memenuhi kewajiban jangka pendeknya (utang), berdasarkan pecking order theory suatu perusahaan yang mempunyai likuiditas yang tinggi akan lebih memilih penggunaan sumber pendanaan secara internal, jika dana internal tidak mencukupi maka perusahaan akan menggunakan pendanaan secara eksternal dan perusahaan yang likuiditas nya tinggi akan lebih cenderung tidak menggunakan pembiayaan dengan utang (Ririt, 2017). 
Menurut Ririt, (2017) perusahaan yang memiliki likuiditas yang tinggi, berarti dana internal juga besar, sehingga menunjukan adanya hubungan negatif dengan leverage, oleh karena itu perusahaan lebih mengutamakan pembiayaan internal sebelum menggunakan pembiayaan eksternal dalam membiayai investasinya.

Menurut Cahyani, (2017) perusahaan tidak akan menggunakan pembiayaan melalui hutang jika perusahaan tersebut mempunyai likuiditas yang tinggi, ini berkaitan dengan pecking order theory. Perusahaan dengan likuiditas yang tinggi menunjukan dana internal yang dimiliki perusahaan besar sehingga perusahaan lebih mengutamakan menggunakan dana internal nya sebelum menggunakan pembiayaan eksternal yaitu dengan cara menerbitkan saham baru. Dalam hal ini menunjukan likuiditas berpengaruh negatif terhadap struktur modal. Jika semakin tinggi kemampuan perusahaan memenuhi kewajiban-kewajiban jangka pendeknya, dapat diartikan bahwa perusahaan tersebut sehat (Cahyani, (2017).

\section{b. Pengaruh Ukuran Perusahaan terhadap Leverage}

Ukuran perusahaan merupakan besar kecil nya suatu perusahaan, perusahaan yang besar membutuhkan dana yang besar pula dari perusahaan kecil, sehingga perusahaan yang besar lebih cenderung menggunakan pinjaman yang besar pula, ukuran perusahaan dapat dilihat dari total asset perusahaan yang berguna untuk kegiatan operasi perusahaan, perusahaan yang memiliki ukuran perusahaan yang besar lebih banyak menggunakan utang dibandingkan dengan ukuran perusahaan kecil, maka hal ini menunjukan adanya hubungan yang positif terhadap kebijakan hutang (Fahmi, 2017). Ukuran perusahaan cerminan besar kecil nya perusahaan yang terlihat dalam nilai total aktiva perusahaan pada neraca akhir tahun, ukuran yang digunakan adalah logaritma natural dari total aktiva, ukuran perusahaan yaitu logaritma natural (Total Aset). Menurut Alib (2014) perusahaan yang berkembang lebih banyak menggunakan dana dari luar perusahaan. Perusahaan besar lebih berani daripada perusahaan kecil dalam mengeluarkan saham baru yang digunakan untuk kebutuhannya membiayai pertumbuhan penjualan. Semakin besar ukuran perusahaan maka juga besar memperoleh akses ke sumber dana serta melakukan investasi. Hal ini menunjukan bahwa ukuran perusahaan berpengaruh terhadap utang, dikarenakan semakin besar perusahaan maka akan membutuhkan dana yang besar pula.

\section{c. Pengaruh Volatilitas Laba terhadap Leverage}

Pendapatan volatilitas mengacu pada seberapa stabil, atau tidak stabil, pendapatan perusahaan. Untuk berinvestasi diperusahaan yang penghasilannya sangat berfluktuasi adalah keputusan berisiko bagi investor. Volatilitas menunjukan perubahan persentase dari pendapatan operasional suatu perusahaan. Sehubungan dengan variabel volatilitas laba, perusahaan dengan volatilitas yang tinggi dari laba memiliki tingkat leverage yang lebih tinggi (Yeo, 2016). Volatilitas laba berarti laba yang berubah-ubah, dalam suatu perusahaan jika mengalami volatilitas laba yang tinggi, maka akan mengalami kesulitan dalam melanjutkan kegiatan operasionalnya, sehingga membutuhkan dana dari pihak luar. Dengan laba yang berubah-ubah membuat perusahaan kesulitan dalam mendapatkan investor, karena investor takut untuk melakukan investasi. Hal ini menunjukan bahwa volatilitas laba berpengaruh terhadap utang, semakin tinggi tingkat volatilitas laba maka, akan semakin tinggi tingkat leverage (Yeo, 2016).

Hipotesis Penelitian

1. Likuiditas berpengaruh negatif dan signifikan terhadap Leverage.

2. Ukuran Perusahaan berpengaruh positif dan signifikan terhadap Leverage.

3. Volatilitas Laba berpengaruh positif dan signifikan terhadap Leverage.

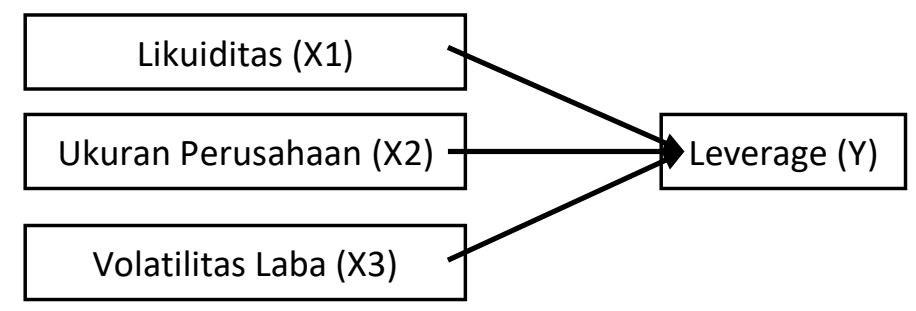

Gambar 1. Kerangka hipotesis

\subsection{Teknik Analisis Data}

Teknik analisis data yang digunakan dalam penelitian ini adalah metode analisis statistik. Analisis data menggunakan EVIEWS 8, yang dimana teknik analisis data yang digunakan oleh peneliti adalah: Statistik Deskriptif Analisis, Uji Asumsi Klasik terdiri dari dalam uji asumsi klasik, yaitu: Uji normalitas data dan Analisis Regresi data panel. Data yang digunakan dalam penelitian ini adalah data sekunder yang didapatkan dari Bursa Efek Indonesia yang telah dipublikasikan. Data yang digunakan merupakan data benar-benar tanpa ada manipulasi yang secara tidak langsung didapatkan dari situs resmi keuangan. Berikut uji kecocokan model yang didapatkan dalam analisis regresi data panel. Analisis ini merupakan kombinasi antara data runtun waktu dan data cross section.

\section{Common Effect Model}

Metode common effect model (CEM) menggabungkan semua data tanpa memikirkan waktu dan tempat penelitian. Diasumsikan bahwa perilaku data antar unit cross- section sama dalam berbagai kurun waktu. Menurut Sukendar dan Zinal (2007) dalam penelitian Wulandari, (2017) pada pendekatan ini diasumsikan bahwa nilai intersep masing-masing variabel adalah sama, begitu pula slope koefisien untuk semua unit cross-section dan time series. 


\section{Fixed Effect Model}

Menurut Gujarati (2003) dalam penelitian (Wulandari, 2017) cara untuk memperhatikan heterogenitas unit cross section pada model regresi data panel yaitu dengan mengizinkan nilai intersep yang berbeda-beda untuk setiap unit cross section tetapi masih mengasumsikan slope konstan.

3. Random Effect Model

Estimasi random effect model ini diasumsikan bahwa efek individu bersifat random bagi seluruh unit cross-section (Wulandari, 2017).

\subsection{Uji Hipotesis}

\section{Uji t (Uji Parsial)}

Uji statistik t menunjukan seberapa jauh pengaruh satu variabel independen secara individual menerangkan variabel dependen. Kriteria pengujian menggunakan taraf signifikansi sebesar 0.05. Apabila nilai t-hitung besar dari t-tabel atau nilai signifikasi $<5 \%$ maka $\mathrm{H} 0$ ditolak atau Ha diterima dan apabila nilai t-hitung kecil dari t-tabel atau nilai signifikasi $\geq 5 \%$ maka $\mathrm{H} 0$ diterima atau Ha ditolak.

\section{HASIL DAN PEMBAHASAN}

\section{Analisis Statistik Deskriptif}

Berdasarkan analisis deskripsi variabel yang telah dilakukan, maka ditampilkan karakteristik yang digunakan dalam penelitian meliputi : Jumlah sampel $(\mathrm{N})$, nilai terendah (minimum), nilai tertinggi (maxsimum), nilai rata-rata sampel (mean) dan standar deviasi pada setiap variabel.

Tabel 2. Descriptive Statistics

\begin{tabular}{cccccc}
\hline & $\mathrm{N}$ & Minimum & Maximum & Mean & Std. Deviation \\
\hline Leverage (Y) & 13 & -29.736 & 11.675 & 0.460 & 3.570 \\
Likuiditas (X1) & 13 & 0.170 & 10.420 & 1.476 & 0.17 \\
Ukuran Perusahaan (X2) & 13 & 18.448 & 26.573 & 23.030 & 29.87 \\
Volatilitas Laba (X3) & 13 & -0.193 & 2.679 & 0.131 & 1.84 \\
\hline & Sumber: data diolah dengan eviews 8 &
\end{tabular}

Pada tabel 2 menunjukan bahwa jumlah data yang digunakan pada penelitian ini adalah 13 sampel perusahaan. Nilai terendah dan nilai tertinggi Leverage, Likuiditas, Ukuran Perusahaan dan Volatilitas Laba dapat dilihat pada tabel diatas. Nilai rata-rata masing-masing variabel, serta standar deviasi dari masing-masing variabel juga ditampilkan pada tabel diatas.

\section{Uji Asumsi Klasik}

Uji Normalitas.

Dalam mendeteksi data terdistribusi secara normal atau tidak normalnya data, pada penelitian ini menggunakan uji Jarquebera dan Probability. Dalam pengambilan keputusan dari uji normalitas ini adalah dengan melihat nilai Jarque-bera dan Probability. Jika nilai Jarque-bera dan Probability $>\alpha=0.05$, maka data tersebut terdistribusi secara normal

Tabel 3. Hasil Uji Normalitas

\begin{tabular}{lrrl}
\hline & JarqueBera & Probabilitas & Kesimpulan \\
\hline CEM & 42.51690 & 0.000000 & Terdistribusi Tidak Normal \\
FEM & 124.9833 & 0.000000 & Terdistribusi Tidak Normal \\
REM & 4.007116 & 0.134855 & Terdistribusi Normal \\
\hline
\end{tabular}

Sumber: data diolah dengan eviews 8

Pada tabel 2 diatas menunjukkan uji Jarque-bera dan Probability dari masing-masing model CEM, FEM, REM. Hal ini dapat disimpulkan bahwa model CEM dan model FEM Jarque-bera 42.51690, 124.9833 dan Probability kecil dari alpha 0.05 dengan demikian menunjukan data terdistribusi tidak normal. Pada model REM nilai jarque-bera 4.007116 dan probabilitas 0.134855 maka data terdistribusi normal. Dilakukan uji lanjut Hausmant Test untuk memilih model terbaik.

Tabel 4. Hasil Hausmant Test

\begin{tabular}{cccc}
\hline & Chi-Sq. Statistic & Chi-Sq. & dfProb \\
\hline Cross-section Random & 7.007842 & 3 & 0.0716 \\
\hline \multicolumn{4}{c}{ Sumber: data diolah dengan eviews 8 }
\end{tabular}


Berdasarkan pengujian, diperoleh nilai probability crosss-section Random besar dari pada alpha $(0,0716>0,05)$ artinya $\mathrm{H} 0$ diterima dan Ha ditolak. Random effect baik dibandingkan fixed effect.

Pemilihan Regresi Data Panel

Hasil estimasi model terbaik pada tabel berikut.

Tabel 5. Hasil Estimasi Model Random Effect

\begin{tabular}{|c|c|c|c|c|c|}
\hline & Coefficient & Std. Error & t-Statistic & Prob. & \\
\hline C & & 958 & 10.76358 & -6.198642 & 0.0000 \\
\hline Likuiditas (X1) & & 511 & 0.095648 & -5.630138 & 0.0000 \\
\hline Ukuran Perusahaan (X & $\mathrm{X} 2)$ & 214 & 9.301532 & 6.109976 & 0.0000 \\
\hline
\end{tabular}

Sumber: data diolah dengan eviews 8

Dari hasil regresi model I diperoleh:

a. Nilai koefisien pada Likuiditas yaitu sebesar -0.538511 dengan probability kecil dari alpha $(0.0000<0.05)$ atau Thitung besar dari Ttabel secara absolut $(-5.630138>2.160)$. Maka Likuiditas berpengaruh negative dan signifikan terhadap Leverage.

b. Koefisien Ukuran Perusahaan sebesar 56.83214 dengan nilai probability kecil dari alpha $(0.0000<0.05)$ atau Thitung besar dari Ttabel secara absolut $(6.109976>2.160)$. Maka Ukuran Perusahaan berpengaruh positif dan signifikan terhadap Leverage.

c. Sedangkan nilai koefisien Volatilitas Laba sebesar -0.003876 dengan nilai probability lebih besar dari alpha (0.9593 $<0.05)$ atau Thitung kecil dari Ttabel secara absolut $(-0.051177<2.160)$. Maka Volatilitas Laba tidak berpengaruh positif dan signifikan terhadap Leverage.

\section{Analisis Regresi Data Panel}

Analisis regresi data panel digunakan untuk mengolah, membahas sampel yang diperoleh serta untuk menilai hipotesis. Variabel C merupakan Konstan, Leverage sebagai variabel dependent (Y) dengan indikator Likuiditas (X1), Ukuran Perusahaan (X2) dan Volatilitas Laba (X3). Hasil pengujiannya pada tabel berikut:

Tabel 6. Tabel Estimasi Regresi Data Panel

\begin{tabular}{lc}
\hline \multicolumn{1}{c}{ Variabel } & Koefisien \\
\hline Konstanta & -66.71958 \\
Likuiditas (X1) & -0.538511 \\
Ukuran Perusahaan (X2) & 56.83214 \\
Volatilitas Laba (X3) & -0.003876 \\
\hline \multicolumn{2}{c}{ Sumber: data diolah peneliti }
\end{tabular}

$$
\boldsymbol{L E V}_{i t}=-\mathbf{6 6 . 7 1 9 5 8}-0.538511 X_{1}+56.83214 X_{2}-0.003876 X_{3}+\boldsymbol{e}
$$

Dari model regresi diatas, -66.71958 sebagai nilai konstanta menerangkan jika diasumsikan nilai variabel independen bernilai 0 (tidak ada), maka nilai variabel leverage bernilai konstan sebesar -66.71958.

Pada Koefisien variabel Likuiditas (X1) -0.538511 maka setiap variabel Likuiditas meningkatan 1 satuan maka variabel leverage turun sebanyak -0.538511. Sedangkan variabel Ukuran Perusahaan (X2) dengan koefisien 56.83214 artinya setiap naiknya variabel ukuran perusahaan sebesar 1 satuan maka variabel leverage naik sebesar 56.83214 serta variabel lain bentuk konstan.

Uji t (Parsial)

Tabel 7. Hasil Uji Hipotesis Analisis Regresi Data Panel

\begin{tabular}{llllll}
\hline Variabel & t-Statistik & t-tabel & Prob. & Alpha & Kesimpulan \\
Likuiditas (X1) & -5.630138 & 2.160 & 0.0000 & 0.05 & H1 diterima \\
Ukuran Perusahaan (X2) & 6.109976 & 2.160 & 0.0000 & 0.05 & H2 diterima \\
Volatilitas Laba (X3) & -0.051177 & 2.160 & 0.9593 & 0.05 & H3 ditolak \\
\hline
\end{tabular}

\section{Sumber: data diolah dengan eviews 8}

Adapun hasil dari pengujian statistik t (uji t) pada penilitian ini adalah sebagai berikut :

Pada variabel Likuiditas secara absolut menunjukkan nilai t-hitung lebih besar dari t-tabel $(-5.630138>2.160)$ atau probability $0.0000<0.05$ maka ini menunjukkan variabel Likuiditas berpengaruh negatif dan signifikan terhadap variabel leverage. Hasil uji t ini berarti mendukung hipotesis 1 (H1). Sedangkan variabel Ukuran Perusahaan menunjukkan nilai absolut t-hitung besar dari t-tabel $(6.109976>2.160)$ atau probability $0.0000<0.05$ maka ini menunjukkan variabel Ukuran Perusahaan berpengaruh positif dan signifikan terhadap variabel leverage. Artinya hasil uji $\mathrm{t}$ ini mendukung hipotesis 2 (H2). Untuk variabel Volatilitas Laba membuktikan nilai absolut t-hitung kecil dari t-tabel $(-0.051177<2.160)$ 
atau probability besar dari taraf signifikansi $(0.9593>0.05)$ artinya variabel Volatilitas Laba terhadap leverage tidak berpengaruh. Artinya, Hipotesis 2 (H2) tidak terbukti.

\subsection{Pembahasan}

Berdasarkan pada pengujian hipotesis yang telah dilakukan dengan melakukan pengujian terhadap persamaan regresi tentang Pengaruh Likuiditas, Ukuran Perusahaan Dan Volatilitas Laba terhadap Leverage Pada Perusahaan yang Terdaftar di Bursa Efek Indonesia. Maka hasil tersebut dapat diperoleh sebagai berikut :

a. Pengaruh Likuiditas terhadap Leverage

Penelitian dengan data observasi berjumlah 13 perusahaan tahun 2010-2020, dengan kriteria tertentu, dengan program eviews 8 maka hipotesis 1 (H1) diduga berpengaruh negatif dan signifikan diterima, Semakin besar likuiditas sebuah perusahaan maka total hutang juga meningkatkan. Perusahaan yang memiliki likuiditas yang tinggi, berarti dana internal juga besar, sehingga menunjukan adanya hubungan negatif dengan leverage, oleh karena itu perusahaan lebih mengutamakan pembiayaan internal sebelum menggunakan pembiayaan eksternal dalam membiayai investasinya (Ririt, 2017).

b. Pengaruh Ukuran Perusahaan terhadap Leverage

Berdasarkan Hipotesis 2 diduga size firm (ukuran perusahaan) terhadap leverage berpengaruh positif dan signifikan. Hasil uji nilai t-hitung membuktikan bahwa $\mathrm{H} 2$ diterima artinya ukuran perusahaan berpengaruh positif dan signifikan terhadap hutang perusahaan. Perusahaan yang memiliki ukuran perusahaan yang besar lebih banyak menggunakan utang dibandingkan dengan ukuran perusahaan kecil, maka hal ini menunjukan adanya hubungan yang positif terhadap kebijakan hutang (Fahmi, 2017).

c. Pengaruh Volatilitas laba terhadap Leverage

Hasil uji hipotesis 3 (H3) menunjukkan bahwa Volatilitas Laba tidak memiliki pengaruh terhadap hutang perusahaan. Artinya, tinggi rendahnya volatilitas laba, tidak mempengaruhi hutang suatu perusahaan. Hal ini tidak sesuai dengan penelitian Yeo (2016) yang mengatakan bahwa volatilitas laba berpengaruh terhadap utang, semakin tinggi tingkat volatilitas laba maka, akan semakin tinggi tingkat leverage. Hasil ini sesuai dengan penelitian Firmansyah et al. (2020) yang menunjukkan bahwa volatilitas laba tidak memiliki pengaruh terhadap biaya utang pada perusahaan, dimana sebagian besar laba perusahaan dalam kondisi yang relatif stabil, namun apabila terjadi ketidakstabilan laba yang terjadi bukan diakibatkan dari kebijakan internal perusahaan. Penggunaan sumber dana internal perusahaan cenderung digunakan oleh perusahaan seperti laba ditahan dibandingkan dana yang bersumber dari pinjaman. Perusahaan yang memiliki ukuran perusahaan yang besar lebih banyak menggunakan utang dibandingkan dengan ukuran perusahaan kecil, maka hal ini menunjukan adanya hubungan yang positif terhadap kebijakan hutang (Fahmi, 2017).

\section{KESIMPULAN}

Hasil penelitian menunjukkan bahwa likuiditas berpengaruh negatif terhadap leverage, sedangkan ukuran perusahaan berpengaruh positif terhadap leverage. Disisi lain, volatilitas laba tidak berpengaruh terhadapap hutang atau leverage perusahaan. Hal ini sejalan dengan penelitian Ririt (2017) yang menyatakan bahwa perusahaan yang memiliki likuiditas yang tinggi, berarti dana internal juga besar, sehingga menunjukan adanya hubungan negatif dengan leverage, oleh karena itu perusahaan lebih mengutamakan pembiayaan internal sebelum menggunakan pembiayaan eksternal dalam membiayai investasinya. Sedangkan Firmansyah et al. (2020) yang menunjukkan bahwa volatilitas laba tidak memiliki pengaruh terhadap biaya utang pada perusahaan, dimana sebagian besar laba perusahaan dalam kondisi yang relatif stabil, namun apabila terjadi ketidakstabilan laba yang terjadi bukan diakibatkan dari kebijakan internal perusahaan.

\section{UCAPAN TERIMAKASIH}

Penulis mengucapkan terima kasih kepada pihak-pihak yang telah membantu dalam penelitian ini. Kepada ketua Sekolah Tinggi Ilmu Ekonomi KBP dan Unit P3M STIE KBP, serta DPRM Kemenristekdikti dan LLDIKTI wilayah X yang telah membantu saya dalam pendanaan hibah penelitian tahun 2021.

\section{REFERENCES}

Alib, Y. A. (2014). Pengaruh Struktur Aset, Profitabilitas, Growth Dan Size Terhadap Struktur Modal Pada Perusahaan Otomotif, 3(1), $1-17$.

Cahyani, N. I. (2017). Pengaruh Profitabilitas , Likuiditas , Size , Kepemilikan Institusional, Dan Tangibility Terhadap Struktur Modal, 6.

Dewi, P. D. A., \& Suaryana, I. G. N. A. (2013). Pengaruh Eps, Der, Dan Pbv Terhadap Harga Saham. E-Jurnal Akuntansi, 1, 215-229 Fahmi, I. (2016). Pegantar Manajmen Keuangan (5th Ed.).

Fahmi, L. Z. U. L. (2017). Pengaruh Struktur Aktiva, Ukuran Perusahaan, Dan Likuiditas Terhadap Struktur Modal Luthfillah Zul Fahmi. Jurnal Ilmu Dan Riset Akuntansi Volume 6, Nomor 2, Februari 2017, 6(Issn : 2460-0585).

Firmansyah, A., Fauzi, Irfan dan Rizal, Yuniar M. Biaya Utang Dari Sudut Pandang Kebijakan Dividen, Volatilitas Laba Dan Kualitas Akrual. Jurnal Studi Akuntansi dan Keuangan Vol. 3(2) (2020), 109 - 129.

Firnanti, F. (2011). Faktor-Faktor Yang Mempengaruhi Struktur Modal Perusahaan Manufaktur. Jurnal Bisnis Dan Akuntansi, 13(2), $119-129$. 
Hidayat, M. S. (2013). Pengaruh Kepemilikan Manajerial, Kebijakan Dividen, Struktur Aktiva, Pertumbuhan Penjualan, Dan Ukuran Perusahaan Terhadap Kebijakan Utang. Jurnal Ilmu Manajemen, 1.

Maulia, H. (2015). Analisis Pengaruh Profitabilitas, Struktur Aset, Likuiditas, Dan Pertumbuhan Penjualan Terhadap Struktur Modal. Jurnal Ilmu \& Riset Akuntansi Vol. 4 No. 7 (2015), 4(7).

Putri, M. E. D. (2012). Pengaruh Profitabilitas, Struktur Aktiva Dan Ukuran Perusahaan Terhadap Struktur Modal Pada Perusahaan Manufaktur Sektor Industri Makanan Dan Minuman Yang Terdaftar Di Bursa Efek Indonesia (Bei), 1(September), 1-10.

Ririt, A. (2017). Pengaruh Ukuran Perusahaan, Pertumbuhan Penjualan, Profitabilitas, Struktur Aktiva, Likuiditas Terhadap Struktur Modal. Jurnal Ilmu Dan Riset Akuntansi Volume 6, Nomor 3, Maret 2017, 6(Issn : 2460-0585), 1268-1289.

Sari, A. N. (2016). Pengaruh Profitabilitas, Likuiditas, Pertumbuhan Aset Dan Ukuran Perusahaan Terhadap Struktur Modal, 5(April), $1-18$.

Sugiyono, P. D. (2017). Metode Penelitian Bisnis. (M. S. Sofia Yustiani Suryandari, S.E., Ed.) (3rd Ed.). Bandung: Alfabeta, Cv. Winarno, Wing Wahyu. (2015). Analisis Ekonometrika Dan Statistika Dengan Eviews (4th Ed.). Yogyakarta: Upp Stim Ykpn.

Windraesti, J. A. (2012). Pengauh Kerakteristik Perusahaan Terhadap Struktur Modal : Studi Empiris Di Bursa Efek. Jrak, 8.

Wulandari, N. (2017). Analisis Faktor-Faktor Yang Mempengaruhi Inflasi Pada Kota Metropolitan Di Indonesia Dengan Menggunakan Analisis Data Panel, 3(2), 34-42.

Yeo, H. (2016a). Solvency And Liquidity In Shipping Companies. Asian Journal Of Shipping And Logistics, 32(4), $235-241$. Https://Doi.Org/10.1016/J.Ajs1.2016.12.007

Yusra, I., Hadya, R., \& Fernandes, J. (2017). Likuiditas , Financial Leverage , Dan Prediktabilitas Beta : Pendekatan, 2(1), 81-91. 